Original Investigation

Orijinal Araștrima

DOI: 10.4274/turkderm.galenos.2018.25492

Turkderm-Turk Arch Dermatol Venereology 2019;53:1-6

\title{
Serum prostate specific antigen levels in women with androgenetic alopecia
}

\author{
Androgenetik alopesisi olan kadınlarda prostat spesifik antijen düzeyleri
}

๑ Gözde Kurtoğlu, ๑ Selma Emre, ๑ Ahmet Metin, ๑ Merve Ergin*, ๑ Özcan Erel*, ๑ Akın Aktaș

Yıldırım Beyazıt University, Atatürk Training and Research Hospital, Clinic of Dermatology; ${ }^{*}$ Clinic of Biochemistry, Ankara, Turkey

\begin{abstract}
Background and Design: The role of androgens in androgenetic alopecia (AGA) patogenesis is well known. Studies set forth that ultrasensitive serum prostate specific antigen (PSA) analysis could be a biochemical marker of hyperandrogenism in women with hirsutism. Serum PSA levels in women with AGA can be used as an indicator of the effect of androgens in target organs. The aim of this study was to investigate serum PSA levels in women with AGA.

Materials and Methods: A total of 100 female patients and a voluntary group of 67 healthy women were evaluated in this research. The diagnosis of AGA was established through history, dermotological evaluation and hair pull test. The degree of hair loss was categorized using the Ludwig scale. Total and free PSA were measured by an "Roche Cobas e 601 immunoassay analyser using the electrochemiluminescence immunoassay" method.

Results: Twenty-nine patients (29\%) had Ludwig 1, 64 (64\%) had Ludwig 2, and 7 (7\%) had Ludwig 3 hair loss. Total testosterone level was significantly higher in patient group than in control group $(p=0.03)$. The levels of free PSA, total PSA, prolactin, ferritin, cortisol, folliclestimulating hormone, luteinizing hormone, and estradiol were within the normal limits in both patient and control groups and there was no statistically significant difference between the groups ( $p>0.05)$.

Conclusion: In our study, there was no statistically significant difference in serum free PSA $(p=0.084)$ and total PSA $(p=0.285)$ levels. However, further large-scale studies are warranted.

Keywords: Prostate specific antigene, androgenetic alopecia, Ludwig
\end{abstract}

Öz

Amaç: Androgenetik alopesi (AGA) patogenezinde androjenlerin etkisi bilinmektedir. Çalışmalar ultrasensitif serum prostat spesifik antijen (PSA) analizinin hirsutizmli kadınlarda hiperandrojenizmin bir biyokimyasal belirteci olabileceğini göstermiştir. Bu nedenle AGA'lı kadınlarda serum PSA değerlerinin, androjenlerin hedef organlardaki etkisinin bir belirteci olarak kullanılabileceği düşünülmektedir. Bu çalışmanın amacı AGA'Iı kadın hastalarda serum PSA düzeylerini araştırmaktır.

Gereç ve Yöntem: Araştırma kapsamında toplam 100 AGA'lı kadın hasta ve 67 sağlıklı kadın gönüllü incelendi. Hastaların AGA tanısı öykü, dermatolojik muayene ve saç çekme testi ile konuldu. Hastalık şiddeti Ludwig evrelemesine göre sınıflandırıldı. Total ve serbest PSA "Roche Cobas e 601 immünoassay analizörde elektrokemilüminesans immünoassay" yöntemiyle çalışıldı.

Bulgular: Çalışmaya alınan hastaların 29'unda (\%29) Ludwig 1, 64'ünde (\%64) Ludwig 2, 7'sinde (\%7) Ludwig 3 düzeyinde AGA tespit edildi. Total testosteron hasta grubunda kontrol grubuna göre anlamlı olarak yüksek bulundu $(p=0,03)$. Serbest PSA, total PSA, prolaktin, ferritin, kortizol, folikül uyarıı hormonu, lüteinleştirici hormon, östradiol düzeyleri hem hasta hem de kontrol gruplarında normal sınırlar içindeydi ve her iki grup arasında anlamlı bir fark bulunmadı.

Sonuç: Çalışmamızda $A G A^{\prime} \mid ı$ kadın hastalar ve sağlıklı kontrol grubu arasında serbest PSA $(p=0,084)$ ve total PSA $(p=0,285)$ serum düzeyleri açısından anlamlı farklılık bulunmadı. Bu konuda geniş hasta gruplarında yaplacak çalışmalara ihtiyaç vardır.

Anahtar Kelimeler: Prostat spesifik antijen, androgenetik alopesi, Ludwig

Address for Correspondence/Yazışma Adresi: Gözde Kurtoğlu MD, Yıldırım Beyazıt University, Atatürk Training and Research Hospital, Clinic of Dermatology, Ankara, Turkey Phone: +90 5069762844 E-mail: gozdetug@hotmail.com

Received/Geliş Tarihi: 20.11.2017 Accepted/Kabul Tarihi: 19.07.2018 ORCID ID: orcid.org/0000-0002-2855-0480

(c) Copyright 2019 by Turkish Society of Dermatology and Venereology

Turkderm-Turkish Archives of Dermatology and Venereology published by Galenos Yayınevi. 


\section{Introduction}

Androgenetic alopecia (AGA) is a non-cicatricial alopecia characterised by the transformation of the terminal hairs to vellus hair with the effect of the peripheral androgens in genetically predisposed individuals. It can affect almost half of the population in various degrees. Generally, it may vary from a receding frontal hairline to alopecia of the whole scalp, in the second and third decades of life ${ }^{1}$. AGA is seen in men and women with different phenotypes. In men, there is generally bitemporal and vertex hair loss. The exposed areas show advancement towards full baldness. In women, on the other hand, the frontal hairline is generally maintained. There is a progressive thinning of the hair around the vertex. However, full baldness does not occur ${ }^{2}$. AGA is seen in women under 50 by $6 \%$ and in women over 70 by $30 \%$ to $40 \%$. Female AGA mostly starts at the $6^{\text {th }}$ decade. There is progressive hair thinning in the frontal and parietal areas. AGA is diagnosed by medical history and physical examination. In cases where this is not sufficient, histopathological examination is required for differential diagnosis.

In women, particularly in those with polycystic ovary syndrome (PCOS) and the effects of hyperandrogenism, acne, and hirsutism accompanying AGA are seen in clinics ${ }^{2}$. The etiology of AGA also comprises of stress, ischemia, and inflammatory, hormonal and genetic factors. Smoking increases AGA significantly. It has been reported that androgens caused follicular miniaturisation ${ }^{3}$. The $5 \alpha$-reductase enzyme activity is increased in male and female patients with $A G A^{4,5}$. It has been found that the number of the androgen receptors in the areas with hair loss was higher than in other areas without any loss ${ }^{6}$. Androgen secreting tumours may cause sudden onset and rampant $A G A^{7}$.

Prostate-specific antigen (PSA) is a serine protease containing an enzymatic activity similar to chymotrypsin, weighing 33-kDa. PSA is produced in the prostate gland in men and secreted into the seminal plasma. Until recent years, PSA has been thought to be produced only in men and in the prostate. Today, PSA is found to be present in females and in non-prostatic tissues. It is proven that PSA is also produced in various female tissues, such as breasts and ovaries, and fluids, such as milk and amniotic fluid ${ }^{8,9}$. Skene (paraurethral) glands, apocrine sweat glands, salivary gland, and breast milk are examples that could be given to the extra-prostatic tissues and fluids in which PSA could be isolated ${ }^{10}$. In extra-prostatic tissues, the secretion of PSA is stimulated by androgens, progestins and glucocorticoids ${ }^{11}$. Thus, hyperandrogenemic situations are expected to exhibit high levels of serum PSA levels. Latest studies showed higher serum PSA levels in hirsutes than in non-hirsutes. Starting from this point, it is being investigated whether PSA could be an androgen marker for hirsutism ${ }^{12,13}$. In AGA, the effects of androgens are apparent, however, the relationship between serum PSA levels, a new marker for hyperandrogenism in women, and AGA has not been investigated yet. This study aims at investigating the relationship of AGA with serum PSA levels, considering the relationship between high serum PSA levels and hyperandrogenism.

\section{Materials and Methods}

Before starting the study, permission was obtained from the local ethics committee of Yıldırım Beyazıt Univesity (approval number: B.30.2.YBÜ.006.06.01/92). Our study had been conducted between October 2012 and March 2013. One hundred consecutive female patients, who had applied to the dermatology outpatient clinic with hair loss problem and who had been diagnosed with AGA, were included in the study. Sixty-seven age-matched healthy volunteers were recruited as the control group. All patients and healthy volunteers were informed about the content of the study and their written informed consent was obtained. The AGA diagnosis was made by the clinical characteristics of the patients determined by scalp examination, detailed patient anamnesis and hair pull test. Patients with inflammatory hair diseases on the scalp, patchy hair loss, alopecia areata and trichotillomania were not included in the study. Patients who did not sign the voluntary informed consent form, who had taken oral contraceptives, systemic corticosteroids, who were receiving hormone replacement therapy, who had cancer and were receiving chemotherapy, who were at their pregnancy or breast feeding period, who had a recent inflammatory disease history, chronic renal and liver failure and who were human immunodeficiency virus-positive were excluded from the study. The control group comprised of women who did not have any known systemic diseases, AGA, infertility, who were not in their pregnancy or breast feeding period, and who did not have any drug use history. The hair pull tests were conducted at multiple zones and patients who were determined positive ( 3 or more hair strands after the pull) were not included in the study. The AGA types of the patients diagnosed with AGA were determined with regard to the Ludwig classification. AGA was defined based on diffuse thinning in the central zone and was evaluated in three types:

Type 1 - Minimal thinning of hair at the central zone maintaining the frontal hairline,

Type 2 - Apparent thinning of hair at the top and

Type 3 - Full or near-full baldness at the top.

The patients aged between 18 and 45 years were categorised as premenopausal, between 45 and 65 years as menopausal, and over 65 as postmenopausal ${ }^{14}$. In the study and the control groups, blood was collected from the antecubital vein using a green $21 \mathrm{G}$ needle after cleaning the zone with alcohol, following an overnight fasting (an average of 10 hours of fasting) in the follicular phase of the menstrual cycle. The thyroid-stimulating hormone (TSH), free T4 (fT4), folliclestimulating hormone (FSH), luteinizing hormone (LH), estradiol (E2), dehydroepiandrosterone sulfate (DHEA-S), total testosterone, prolactin, cortisol, ferritin, vitamin B12, zinc, basal insulin, and fasting blood glucose values were measured the same day. Blood samples collected for measuring free and total PSA were put into biochemistry tubes with yellow caps with $10 \mathrm{cc}$ gel. They were centrifuged at $3600 \mathrm{rpm}$ for 10 minutes and separated to their serums. The samples were transferred to the additive-free tubes and stored in deep freeze (Sanyo, Japan) at $-80^{\circ} \mathrm{C}$ degrees until assay. The total and free PSA measurements were conducted with the serum samples. The total and free PSA analyses were conducted on a [Roche Cobas e 601 immunoassay analyser using the electrochemiluminescence immunoassay] method.

\section{Statistical Analysis}

Continuous data are summarized in the form of median (minimummaximum) and categorical data in the form of frequency counts and percentages. The Mann-Whitney $U$ test and Kruskal-Wallis test were used for comparison of the groups. When a p value proved meaningful based on the Kruskal-Wallis test result, dual comparisons were carried 
out with Bonferroni-corrected Mann-Whitney U test. A chi-square and Fischer's exact test were used for comparison of categorical data. Analyses were made using SPSS v.15. A p value of less than 0.05 value was considered statistically significant.

\section{Results}

The mean age of the patients and controls was 40.59 113.97 (1975) years and $42.4 \pm 14.01$ (18-78) years, respectively. There was no statistically significant difference in age and hormonal period between the patient and control groups ( $p>0.05)$. The distribution of the patients and healthy volunteers with reference to the hormonal periods is presented in Table 1. The mean age of AGA onset in the patient group was 38.49 \pm 14.04 (18-70) years.

In the patient group, 26 patients had accompanying diseases. Seventeen of these patients had Hashimoto's thyroiditis, the thyroid function test was within the normal limits, and they were not using medication. Nine patients had type 2 diabetes mellitus and they were using oral metformin.

The AGA severity of the patients diagnosed with AGA was determined using the Ludwig scale. AGA was evaluated in three types according to the Ludwig classification. Twenty-nine patients (29\%) were found to have Ludwig type 1 AGA (Figure 1), 64 (64\%) - Ludwig type 2 (Figure 2), and 7 patients (7\%) - Ludwig type 3 (Figure 3) AGA.

In 58 patients, there was an accompanying hyperandrogenism. The accompanying hyperandrogenism findings are presented in Table 2. Forty-eight patients had a family history of AGA with 9 in father and 39 in mother.

Table 1. Hormonal period specifications of the patient group and the control group

\begin{tabular}{|l|l|l|l|}
\hline & Patient & Control & $\mathbf{p}$ \\
\hline Premenopausal (n, \%) & $54(54 \%)$ & $41(61.2 \%)$ & 0.399 \\
\hline Menopausal (n, \%) & $14(14 \%)$ & $11(16.4 \%)$ & 0.399 \\
\hline Postmenopausal (n, \%) & $32(32 \%)$ & $15(22.4 \%)$ & 0.399 \\
\hline $\begin{array}{l}\text { Age (years) median } \\
\text { (minimum-maximum) }\end{array}$ & $\begin{array}{l}39.5(19- \\
75)\end{array}$ & $40(18-78)$ & 0.354 \\
\hline
\end{tabular}

Table 2. Accompanying hyperandrogenism findings in patient group

\begin{tabular}{|l|l|l|}
\hline Disease & Number & $\%$ \\
\hline Menstrual disorder & 18 & 18 \\
\hline AGA family history & 48 & 48 \\
\hline Hirsutism & 22 & 22 \\
\hline Acne & 34 & 34 \\
\hline Insulin resistance & 7 & 7 \\
\hline Hypercortisolism & 12 & 12 \\
\hline Seborrhea & 40 & 40 \\
\hline PCOS & 0 & 0 \\
\hline AGA: Androgenetic alopecia, PCOS: Polycystic ovary syndrome \\
\hline
\end{tabular}

The level of DHEA-S was higher than the normal in 8 patients and 4 controls. However, there was no significant difference in DHEA-S values between the patient and the control groups $(p=0.143)$.

When the patient group and control group were compared, total testosterone was found to be significantly higher in the patient group than in the control group $(p=0.03)$. Free PSA, total PSA, prolactin, ferritin, cortisol, FSH, LH, and E2 levels were within the normal range in both the patient and the control groups with no statistically significant difference between these two groups ( $p>0.05$ ). Table 3 presents the hormonal parameters of the patient group and the control group.

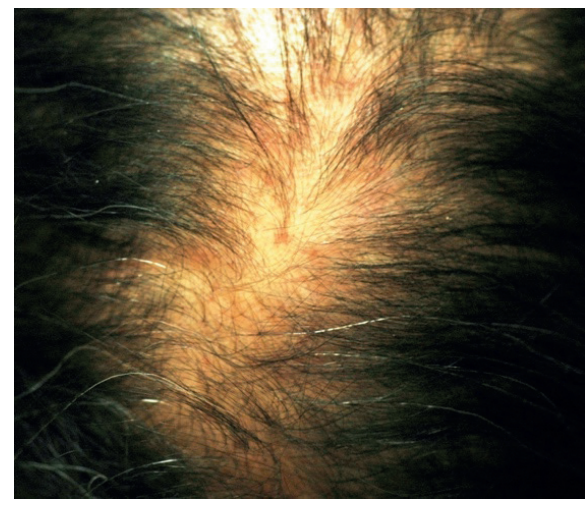

Figure 1. Ludwig type 1

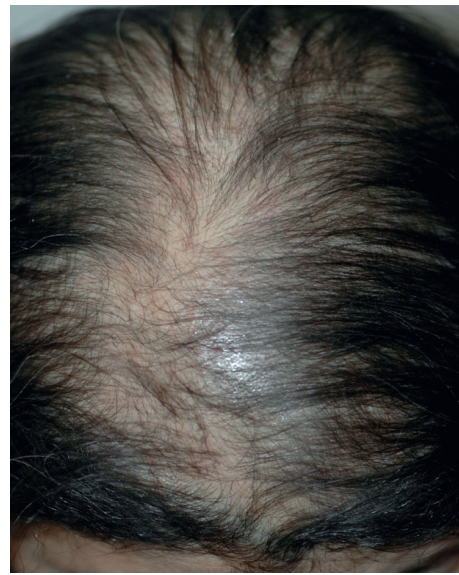

Figure 2. Ludwig type 2

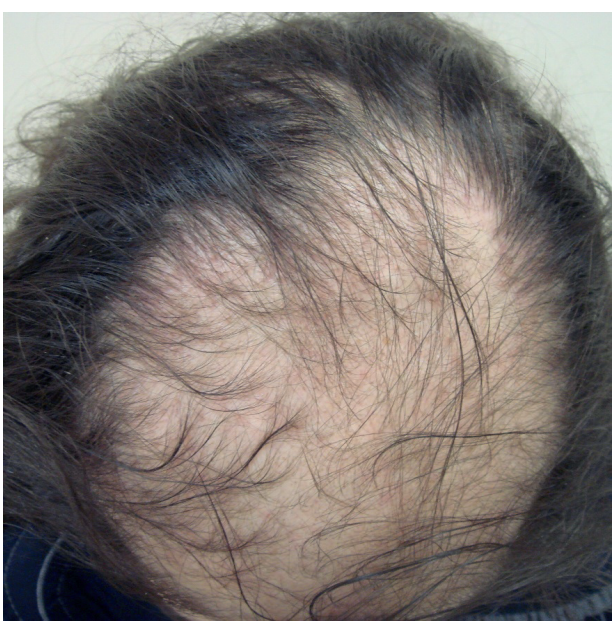

Figure 3. Ludwig type 3 
Table 3. Comparison of hormonal parameters of the patient group and the control group

\begin{tabular}{|l|l|l}
\hline Patient & Control & $\mathbf{p}$ \\
\hline
\end{tabular}

\begin{tabular}{|l|l|l|l|}
\hline \multicolumn{2}{|l|}{ Free PSA } \\
\hline $\begin{array}{l}\text { Median (minimum-maximum) } \\
(\mathrm{ng} / \mathrm{mL})\end{array}$ & $\begin{array}{l}0.010 \\
(0.01-0.014)\end{array}$ & $\begin{array}{l}0.010 \\
(0.01-0.014)\end{array}$ & 0.084 \\
\hline
\end{tabular}

\section{Total PSA}

Median (minimum-maximum)

$(\mathrm{ng} / \mathrm{mL})$

\section{DHEA-S}

Median (minimum-maximum) $(\mathrm{ug} / \mathrm{dL})$

\section{Testosterone}

Median (minimum-maximum) $(\mathrm{ng} / \mathrm{mL})$

0.2535

(0.03-0.32)
0.003

$(0.003-0.162)$
0.285

155.7

(7.39-555.4)
0.143

\section{Prolactin}

Median (minimum-maximum)

(ng/mL)
10.80

(2.0-118.3)
0.21

$(0.03-0.48)$
0.03

PSA: Prostate specific antigen, DHEA-S: Dehydroepiandrosterone sulfate

\section{Discussion}

While AGA is frequently acknowledged as a marker of hyperandrogenism in women, it is believed to occur in men because of the increase in the local androgen metabolism. Increased 5 $\alpha$-reductase enzyme activity has been reported in women and men with $A G A^{15}$. It has also been reported that there was no biochemical anomaly in more than $60 \%$ of women with alopecia only ${ }^{15,16}$. In our study, the free PSA, total PSA, DHEA-s, prolactin, ferritin, cortisol, FSH, LH, and E2 levels were within the normal range and there was not any statistically significant between the two groups.

Schmidt et al. ${ }^{17}$, found a statistically significant increase in serum cortisol levels in $18 \%$ of male and female patients indicating the contribution of the adrenal glands. Hyperandrogenism may depend on either excessive secretion of serum cortisol or increased end organ response. Juricskay and Telegdy ${ }^{18}$ found elevated C19 metabolites of testosterone and androstenedione and hyperandrogenemia and increased cortisol and corticosterone metabolite in approximately $86 \%$ of 56 female patients with AGA. In our patient group, hypercortisolism was found in $12 \%$ of patients. In the control group, this value was $8 \%$. There was no statistically significant difference in cortisol levels between the patient and control groups.

Kasick et al. ${ }^{19}$ showed that there was an abnormal androgen metabolism in female patients with premenopausal AGA. In this study, while the serum testosterone and sex hormone binding globulin levels were found to be normal, a significant increase in DHEA-S levels was found. In our study, 8 individuals in the patient group and 4 in the control group had above normal DHEA-S levels. On the other hand, there was no statistically significant difference in DHEA-S levels between the patient and the control groups.

Futterweit et al. ${ }^{20}$ evaluated 109 female patients diagnosed with diffuse pattern AGA in terms of endocrine dysfunction, and found hyperandrogenism in $38.5 \%$ of patients. In our study, 58 (58\%) patients were found to have hyperandrogenism findings. AGA is one of the hyperandrogenism findings. Other hyperandrogenism findings are acne, hirsutism and menstrual disorders, and PCOS may accompany in some patients ${ }^{21}$. In their study including 59 female patients aged 16-40 years and diagnosed with AGA, Borlu et al. ${ }^{22}$ found that $40 \%$ of patients had hirsutism, 25\% - acne, 25\% - seborrhea and 37\% had PCOS.

In our study, too, acne, hirsutism, seborrhea and menstrual disorder were the most frequently accompanying hyperandrogenism findings. On the other hand, in our study, while a statistically significant increase in the hormonal values was found with regard to hyperandrogenism the fact that accompanying clinical signs were not evident except for AGA was thought to be stemming from androgen receptor polymorphism. The changes in the androgen receptor genes are more frequent than in other steroid receptor genes and it is thought that the aforementioned polymorphism could affect androgen sensibility and phenotypic appearance. Due to the differences in the receptor genes, end organ response may cause different clinical findings than the serum androgen levels.

Vierhapper et al. ${ }^{23}$ found that the testosterone production increased in women with AGA, however, dihydrotestosterone levels did not change. In our study, the testosterone levels in patients with AGA were found to be significantly increased. This increase was more apparent in patients with Ludwig type 3, and there was a significant difference between controls and only this group. These results are important for indicating the role of testosterone in the development of AGA in women.

It has been reported that first-degree family history of AGA was less common in women than in men ${ }^{24}$. A study found a family history in $48 \%$ of men with AGA and $45 \%$ of women with $A G A^{25}$. In our study, family history was present in 48 (48\%) female patients with AGA. However, there was no first-degree family history of AGA in the control group. 
As PSA concentrations are lower in females than in males, PSA could not be found in female serum with the analysis methods known until very recently. With the ultrasensitive immune analysis technique, serum PSA levels can be measured in women now. In studies on this topic, PSA could be found in the serums of $50 \%$ of normal females with the development of very sensitive immunoflourometric PSA analysis methods ${ }^{26-28}$. Studies using ultrasensitive serum PSA analysis showed that PSA could be a biochemical marker for hyperandrogenism in women with hirsutism ${ }^{12,29,30}$. There are a limited number of studies on the relationship between idiopathic hirsutism and serum PSA, and the findings are contradictory ${ }^{12,13,31,32}$.

Negri et al. ${ }^{29}$ indicated a decrease in serum PSA concentration during hirsutism treatment with different antiandrogenic drugs including flutamide. Thus, it was stated that serum PSA could be an ideal marker for monitoring treatments with drugs blocking the androgen receptors such a flutamide, or for patients with non-hyperandrogenic hirsutism ${ }^{16,29}$. Cebeci et al..$^{33}$ found higher levels of serum PSA in hirsute women with PCOS than in women with idiopathic hirsutism, although it did not create a statistically significant difference. This situation was most probably due to women with PCOS having higher levels of serum testosterone levels.

Increased serum androgens were causing an increase in serum PSA levels in these patients. In another study, significantly higher levels of serum PSA were found in hirsute women than in controls ${ }^{34}$. In our study, the maximum values of free PSA were higher in the patient group, however, there was not any statistically significant difference in PSA levels between the patient and control groups.

The levels of androgens such as testosterone and DHEA-S, which are present in the serum, could be measured by laboratory methods. However, the effects of androgens on tissues such as skin and hair do not follow the serum levels. It is thought that the differences in the androgen receptor genes play a role in determining the response of the peripheral tissues to the androgens. Thus, measurement of PSA, which is a molecule secreted with the effect of the androgens, may be a more valuable finding than the measurement of the androgen serum levels in showing the androgen effect on the peripheral tissues. In our study considering the relationship between high levels of serum PSA and response of the organs targeted by the androgens, we investigated the relationship between female AGA and high levels of serum PSA. In our study, there was not any statistically significant difference in free and total PSA values between the patient and the control groups. It is believed that these results are due to the limited number of patients and the very low number of patients with Ludwig type 3 AGA, which shows a significantly higher testosterone levels compared to controls. In the future, serum PSA in women with AGA could be used as a marker for the androgen effect on the androgen-sensitive tissues. However, this topic requires further studies to be conducted on larger patient groups.

\section{Study Limitation}

The limited number of our patients (especially those with Ludwig Type 3 AGA, whose testosterone levels were significantly higher compared to controls) was the limitation of our study.

\section{Conclusion}

In our study, considering the relationship between high levels of serum PSA and response of the organs targeted by the androgens, we investigated the relationship between female AGA and high levels of serum PSA. In our study, there was not any statistically significant difference between the patient and the control groups in terms of free and total PSA values. It is believed that these results are due to the limited number of patients and very low number of patients with Ludwig type 3 AGA, which shows a significantly higher testosterone levels compared to controls. In the future, serum PSA in women with AGA could be used as a marker for the androgen effect on the androgen-sensitive tissues. However, this topic requires further studies to be conducted on larger patient groups.

\section{Ethics}

Ethics Committee Approval: Yıldırım Beyazıt University Faculty of Medicine, Ethical Board Approval has been obtained (approval number: B.30.2.YBÜ.006.06.01/92)

Informed Consent: Written informed consent was obtained from all participants.

Peer-review: External and internal peer-reviewed.

\section{Authorship Contributions}

Surgical and Medical Practices: G.K., S.E., Concept: G.K., S.E., Design: G.K., S.E., Data Collection or Processing: G.K., S.E., Analysis or Interpretation: G.K., S.E., A.A., A.M., Ö.E., M.E., Literature Search: G.K., Writing: G.K., S.E.

Conflict of Interest: No conflict of interest was declared by the authors.

Financial Disclosure: The authors declared that this study received no financial support.

\section{References}

1. Şendur N, Karaman G. Androgenetik alopesi. ADÜ Tıp Fakültesi Dergisi 2000;1:39-46. http://adudspace.adu.edu.tr:8080/jspui/ handle/11607/2249.

2. Venning VA, Dawber RPR. Patterned androgenic alopecia in women. J Am Acad Dermatol 1988;18:1073-7.

3. Berker DAR, Messenger AG, Sinclair RD. Disorders of Hair. In: Burns $T$ Breathnach S, Cox Neil, Griffihs C (eds): Rook's Textbook of Dermatolgy (7th ed) Volume four. Blackwell Publishing, 2004, pp. 63.8-63.10.

4. Guarrera M, Rebora A. Kenogen in female androgenetic alopecia. A longitudinal study. Dermatology 2005;210:18-20.

5. Camacho-Martinez FM. Hair loss in women. Semin Cutan Med Surg 2009;28:19-32.

6. Nakanishi J. Expression of androgen receptor, type I and type II 5-reductase in human dermal papilla cells. In: van Neste D, Randall VA (eds). Hair research for the next millennium. Amsterdam: Elsevier Sience,1996:307-10

7. Randal VA. Androgens and hair growth. Dermatol Ther 2008;21:314-28.

8. Diamandis EP, Yu H. New biological functions prostate spesific antigen. J Clin Endocrinol Metab 1995;80:1515-7.

9. Diamandis EP. Prostate spesific antigen-new applications in breast and other cancers. Anticancer Res 1996;16:3983-4.

10. Diamandis EP, Yu H. Nonprostatic sources of prostate-specific antigen. Urol Clin North Am 1997;24:275-82

11. Young $C Y$, Montgomery $B T$, Andrews $P E$, et al. Hormonal regulation of prostate-specific antigen messenger RNA in human prostatic adenocarcinoma cell line LNCaP. Cancer Res 1991;51:3748-52.

12. Melegos DN, Yu H, Ashok $\mathrm{M}$, et al. Prostate-specific antigen in female serum, a potential new marker of androgen excess. J Clin Endocrinol Metab 1997:82:777-80

13. Escobar-Morreale HF, Avila S, Sancho J. Serum prostate-specific antigen concentrations are not useful for monitoring the treatment of hirsutism with oral contraceptive pills. J Clin Endoc Metab 2000;85:2488-92.

14. Çelik AS, Pasinlioğlu T. Klimakterik dönemde yaşanan semptomlar ve hemşirenin rolü. ERÜ Sağlık Bilimleri Dergisi 2013;1:48-56. 
15. Tosti A, Camacho-Martinez F, Dawber R: Management of androgenetic alopecia. JEADV 1999;12:205-14.

16. Kaufman KD. Androgens and alopecia. Mol Cell Endocrinol 2002;30:198:8995.

17. Schmidt S, Fischer TW, Chren MM et al. Strategies of coping and quality of life in women with alopecia. Br J Dermatol 2001;144:1038-43.

18. Juricskay S, Telegdy E. Urinary steroids in women with androgenic alopecia. Clin Biochem 2000;33:97-101.

19. Kasick JM, Bergfeld WF, Steck WD, Gupta MK. Adrenal androgenic femalepattern alopecia: sex hormones and the balding woman. Cleve Clin Q 1983;50:111-22.

20. Futterweit $W$, Dunaif $A$, Yeh $H C$, Kingsley $P$. The prevalence of hyperandrogenism in 109 consecutive female patients with diffuse alopecia. J Am Acad Dermatol 1988;19:831-6.

21. Han A, Mirmirani P: Clinical approach to the patient with alopecia. Semin Cutan Med Surg 2006;25:11-23.

22. Borlu M, Ukşal Ü, Utaş S, ve ark. Androgenetik alopesili 59 kadın hastada hiperandrojenizm ve polikistik over sendromu. Türkderm 2004;38:106-10.

23. Vierhapper $\mathrm{H}$, Maier $\mathrm{H}$, Nowotny $\mathrm{P}$ et al. Production rates of testosterone and of dihydrotestosterone in female pattern hair loss. Metabolism 2003;52:927-9

24. Han ES, Kim MN, Hong CK, Ro BI. A clinical study of androgenetic alopecia. Korean J Dermatol 1995;33:44-52.

25. Paik JH, Yoon JB, Sim WY, et al. The prevalence and types of androgenetic alopecia in Korean men and women. Br J Dermatol 2001;145:95-100.
26. Ferguson RA, Yu H, Kalyvas $M$, et al. Ultra-sensitive detection of prostatespecific antigen by a time-resolved immunofluorometric assay and the Immulite ${ }^{\circledR}$ immunoche-miluminiscent third generation assay: potential applications in prostate and breast cancer. Clin Chem 1996;42:675-84.

27. Yu H, Diamandis EP. Measurement of serum prostate specific antigen levels in women and in prostatectomized men with an ultrasensitive immunoassay technique. J Urol 1995;153:1004-8.

28. Diamandis EP, Yu H, Melegos DN. Ultrasensitive prostate specific antigen assays and their clinical application. Clin Chem 1996;42:853-7.

29. Negri C, Tosi F, Dorizzi R, et al. Antiandrogen drugs lower prostate spesific antigen (PSA) levels in hirsute subjects: evidence that serum PSA is a marker of androgen action in women. J Clin Endocrinol Metab 2000;85:81-4.

30. Bahceci M, Bilge $M$, Tuzcu $A$, et al. Serum prostate specific antigen levels in women with polycystic ovary syndrome and the effect of flutamide+desogestrel/ethinyl estradiol combination. J Endocrinol Invest 2004:27:353-6.

31. Kocak M. Serum levels of prostate-specific antigen and androgens after nasal administration of a gonadotropin releasing hormone-agonist in hirsute women. Gynecol Endocrinol 2004;18:179-85.

32. Galadari I. Al-Mazroei M, Alkaabi J. Prostatic-specific antigen and idiopathic hirsutism in females. Int J Dermatol 2004;43:275-7.

33. Cebeci F, Onsun N, Ümmetoğlu O, ve ark. Hirsutizmli kadınlarda serum prostatik spesifik antijen düzeyleri. Türkderm 2009;43:104-6.

34. Vural B, Ozkan S, Bodur H. Is prostate-specific antigen a potential new marker of androgen excess in polycystic ovary syndrome. J Obstet Gynaecol Res 2007;33:166-73. 